\title{
II. СУСПІЛЬНО-ГЕОГРАФІЧНІДОСЛІДЖЕННЯ
}

http://doi.org/10.17721/1728-2721.2020.76-77.5

УДК 911.3.30 (477)

М. Барановський, д-р геогр. наук, профр. ORCID iD: 0000-0002-0771-1126 Ніжинський державний університет імені Миколи Гоголя, Ніжин, Україна

\section{СУБРЕГІОНАЛЬНИЙ РІВЕНЬ АДМІНІСТРАТИВНО-ТЕРИТОРІАЛЬНОЇ РЕФОРМИ В УКРАЇНІ: ДИСКУСІЙНІ АСПЕКТИ}

\begin{abstract}
В Україні розпочався другий етап децентралізації, пов'язаний із формуванням адміністративно-територіальних одиниць субрегіонального рівня. Затверджений Верховною Радою Украйни перелік нових районів містить низку дискусійних моментів, які потребують наукового аналізу. У дослідженні проаналізовано підходи науковців до виділення в Україні адміністративних одиниць субрегіонального рівня, розкрито аргументи прибічників та противників їхнього створення в сучасних умовах. На основі аналізу кількісних критеріїв установлено, що нові райони відповідають рівню NUTS-3 стандарту територіального поділу країн ЄC. Здійснено порівняльний аналіз схем поділу країни на райони, які були розроблені різними урядами Украӥни, із мережею районів, затверджених Верховною Радою у 2020 р. Установлено, що збільшення кількості нових районів зі 102 до 129, а потім до 136 одиниць відбулося внаслідок розширення їхньої мережі на тимчасово окупованих територіях Донбасу та в Криму, а також під тиском представників регіонів. На прикладі Чернігівської області розкрито складність питання формування мережі нових районів та їхніх центрів. Визначено, що пересічна кількість населення нового району становить в Україні 303 тис. осіб, людність центру адміністративних одиниць субрегіонального рівня - 130 тис. осіб. Установлено наявність дуже значних диспропорцій (від 58 до 362 разів) у кількості населення в нових районах та їхніх центрах. На основі проведених обчислень визначено, що 26,5\% нових районів та 50 \% їхніх иентрів мають кількість населення меншу, ніж це визначено нормативними документами, що може стати додатковою перешкодою для формування якісного кадрового потенціалу органів виконавчої влади. Установлено, що конкурентна боротьба між містами за статус центру нового району зумовлена прагненням місцевих еліт зберегти за собою контроль над певними територіями. Указано на неоднозначне сприйняття в середовищі експертів і регіональних еліт питання створення нових районів за етнічною ознакою (Болградський і Берегівський райони). Визначено перелік кадрових, фінансових, майнових питань, які необхідно буде розв'язати задля побудови в Україні ефективної виконавчої влади на субрегіональному рівні.
\end{abstract}

Ключові слова: адміністративно-територіальна реформа, субрегіональний рівень управління, нові райони, адміністративно-територіальний устрій, децентралізація.

Актуальність дослідження. Децентралізація наразі вважається однією з найуспішніших реформ в Україні після зміни влади та відомих подій 2014 р. Важливим складником широкого поняття "децентралізація" є реформування адміністративно-територіального устрою країни. Цей процес розпочався ще 2015 р. після прийняття рішення Урядом країни та розроблення відповідних нормативних документів. Майже п'ять років триває перший етап децентралізації, пов'язаний із формуванням самодостатніх об'єднаних територіальних громад. Наразі процес ще не завершився, проте нарешті на рівні Кабінету Міністрів України затверджені перспективні плани формування громад, які повністю покривають усю територію країни. Це дозволяє сподіватися, що до місцевих виборів восени 2020 р. перший етап адміністративно-територіальної реформи буде завершено. Другим етапом реформи адміністративно-територіального устрою України в рамках процесу децентралізації є формування нових, укрупнених районів. На відміну від створення об'єднаних громад, яке триває вже п'ять років, фрормування нових районів проводиться у дуже стислі терміни. За таких обставин виникло чимало дискусійних питань, які потребують широкого обговорення в географічній спільноті.

Аналіз останніх досліджень і публікацій. Перші наукові дослідження з питань реформування адміністративно-територіального устрою України з'явилися ще в середині 90-х рр. XX ст. У цьому контексті варто зазначити роботи М. Дністрянського $[11 ; 12]$. Зростання кількості наукових публікацій із проблематики адміністративно-територіальної реформи відбулося під час першої спроби реалізації ії ідей у середині 2000-х років. Із 2014 р., коли створення об'єднаних територіальних громад набуло реальних обрисів, питання децентралізації та реформування адміністративного-територіального устрою країни почали жваво дискутуватися в засобах масової інформації, наукових публікаціях, а сам процес за влучним означенням учених Інституту регіональних досліджень "... перетворився на децентралізаційний марафон" [22, с. 6]. Для розуміння сутності процесів децентралізації вагомими $€$ наукові напрацювання Ю. Ганущака [7], А. Ткачука [25], В. Куйбіди [3], а також дослідження, в яких здійснено аналіз міжнародного досвіду проведення адміністративно-територіальної реформи [4, с. 113-150; 18]. Широкий спектр прикладних питань функціонування територіальних громад, зокрема адміністративно-фрінансова децентралізація, транскордонне співробітництво, фрінансово-економічний потенціал, ризики реформи децентралізації знайшли відображення в низці досліджень фахівців із регіональної економіки $[6,22]$. Серед представників суспільно-географічної науки зазначимо наукові праці М. Барановського з різних аспектів децентралізації [5], В. Удовиченка, А. Мельничука, О. Гнатюка та П. Остапенка $[13 ; 26]$ - $з$ аналізу процесів децентралізації влади, Я. Олійника та П. Остапенка [17] - із проблематики формування спроможних територіальних громад в Україні й Полтавській області, 3. Тітенко [24] - із оцінки проблем і перспектив адміністративно-територіальної реформи в Україні.

Водночас зауважимо, що левова частка наукових праць із проблематики адміністративно-територіальної реформи стосувалася ії першого етапу - етапу формування об'єднаних територіальних громад. Щодо реформи субрегіонального рівня, то вагомих наукових напрацювань із цього питання обмаль. У даному контексті варто підкреслити розробки О. Соскіна та П. Масляка [2], які пропонували запровадити в Україні дворівневу модель територіального устрою, де основними адміністративними одиницями мали би стати громади та паланки, а також дослідження агломерацій та субрегіонів, виконане за сприяння агентства USAID [23]. 
Через брак часу Кабінет Міністрів України 14 червня 2020 р. затвердив перспективний план адміністративних одиниць субрегіонального рівня. Однак він містив низку дискусійних питань, свідченням чого є протести представників окремих територіальних громад і районів, а також зміни, які були внесені до зазначеного плану під час його розгляду у Верховній Раді України. Зрештою, Постановою № 807-IX "Про утворення та ліквідацію районів" від 17 липня 2020 р. Верховна Рада України затвердила нові райони [19]. Прийняття Постанови не спростовує потреби пошуку відповіді на низку питань: 1) наскільки оптимальною $є$ нова мережа адміністративних одиниць субрегіонального рівня; 2) чи відповідають майбутні утворення чинним критеріям їхнього виокремлення; 3) у яких регіонах країни поділ на райони є найбільш дискусійним; 4) які питання подальшого функціонування нових районів потребують особливої уваги.

Мета (завдання) дослідження. Головною метою дослідження $€$ аналіз дискусійних аспектів адміністративнотериторіальної реформи субрегіонального рівня в Україні, установлення відповідності нових районів чинним вимогам нормативно-законодавчої бази та визначення проблемних питань їхнього подальшого функціонування.

Методика та методологія. Інформаційною основою для проведення дослідження були оперативні дані Міністерства розвитку громад і територій України, офріційної інтернет-платформи "Децентралізація" та державної служби статистики України. Загальний алгоритм дослідження включав низку взаємопов'язаних процедур - від аналізу нормативної бази, оцінки доцільності реформування адміністративно-територіального устрою до визначення дискусійних питань мережі нових районів у розрізі регіонів України. Методологічну основу дослідження становили наукові праці авторів ідеї децентралізації, дослідження з вивчення міжнародного досвіду реформування адміністративного-територіального устрою, прикладні розробки науковців у царині регіонального розвитку та децентралізації. При проведенні дослідження аналізувалися також матеріали круглих столів, прес-конференцій, які проводилися представниками Міністерства розвитку громад і територій та Верховної Ради України. Для виявлення диспропорцій у мережі проєктних районів, людності їхніх центрів оцінювалися показники динаміки кількості населення. Для ілюстрації відмінностей у підходах до виділення міжрайонних територіальних систем у сфрері фінансів, медицини та нових районів у Чернігівській області використовувався картографрічний метод дослідження.

Виклад основних результатів дослідження. Потреба в реформуванні адміністративно-територіального устрою України назріла доволі давно, адже він донедавна лишався незмінним, попри докорінну трансформацію суспільно-правових відносин після розпаду СРСР. Підходи до виокремлення та кількісні критерії нових адміністративно-територіальних одиниць з'явилися в Україні ще під час першої спроби реформування її територіального устрою у 2004-2005 рр. У той період розглядалося питання переходу до трирівневої системи управління - громада-район (місто-район)-регіон. Громади мали би стати базовою одиницею адміністративно-територіального устрою. Нижній кількісний ценз для громад тоді було встановлено на рівні 5 тис. осіб. У районах і містах-районах кількість населення мала б становити не менш ніж 70 тис. осіб. Попри те, що на рівні регіонів активно проходило обговорення цього питання [1], що було розроблено пілотні проєкти нових адміністративних одиниць у кількох регіонах країни, реформа завершилася фактично не розпочавшись.
У 2014 р. передумови для запровадження децентралізації та реформування адміністративно-територіального рівня були зовсім іншими. На рівні центральних і регіональних органів влади, а також громадян країни було чітке усвідомлення необхідності реформування системи управління, розподілу повноважень і фінансових ресурсів, яке тісно пов'язувалося з необхідністю зміни адміністративнотериторіального устрою. Відносно успішному старту реформи децентралізації сприяли також належна нормативно-правова база та активна рекламна компанія щодо роз'яснення ії цілей, завдань і очікуваних результатів.

Обґрунтування доцільності проведення адміністративно-територіальної реформи базувалося на кращих практиках її успішної реалізації в країнах ЄС. У цьому об'єднанні потреба в реформуванні адміністративно-територіальних одиниць, насамперед, для виділення проблемних територій у рамках загальноєвропейської регіональної політики, виникла ще кінці 80-х рр.. XX ст. Наслідком такого реформування стала нова Номенклатура територіальних одиниць (NUTS), яка включає п'ять ієрархічних рівнів. Єдині для ЄС кількісні параметри визначені лише для перших трьох рівнів територіальних одиниць. Для рівня NUTS-1 кількість населення має бути понад 3 млн осіб, NUTS-2 - від 800 тис. до 3 млн осіб, NUTS-3 - від 150 до 800 тис. осіб. Країни Східної Європи, які стали членами $€ C$ на початку XXI ст., також провели реформу адміністративно-територіального устрою.

Оскільки у 2020 р. процес формування об'єднаних територіальних громад має завершитися, то логічно постало питання про другий етап реформи, який пов'язаний зі створенням адміністративних одиниць субрегіонального рівня. Для їхнього означення пропонувалося використовувати терміни "повіти", "округи", "укрупнені райони" тощо. Однак на цей час, зважаючи на усталено практику, для позначення адміністративних одиниць субрегіонального рівня використовується термін "район".

Питання створення нових адміністративних одиниць субрегіонального рівня активно дискутується на рівні експертів, управлінців, представників регіональних органів влади та органів місцевого самоврядування як до, так $\mathrm{i}$ після їхнього офріційного затвердження. У цьому контексті варто розглянути аргументи "за" та "проти".

Активними прихильниками створення нових районів $€$ такі науковці та практики, як Ю. Ганущак, І. Коліушко, В. Куйбіда, В. Негода, А. Ткачук. Це не дивно, адже вони фактично $\epsilon$ авторами ідеї та ініціаторами запровадження в Україні адміністративно-територіальної реформи. 3 урахуванням їхнього бачення, яке викладене в наукових публікаціях, що наведені вище, на прес-конференціях, в інтерв'ю [10; 20], а також власного аналізу можна навести низку аргументів стосовно доцільності створення адміністративних одиниць субрегіонального рівня. По-перше, уже на сьогодні у низці регіонів об'єднані територіальні громади (ОТГ) повністю покрили всю територію району, що призводить до дублювання їхніх функцій. Після завершення першого етапу реформи потреба в районах повністю відпаде. По-друге, реформа дозволить перейти до трирівневої системи адміністративно-територіального устрою - громада - район - регіон. По-третє, маючи прагнення в перспективі стати членом Європейського Союзу (ЄC), Україна має виконати ряд "домашніх завдань", у т. ч. увідповіднити до стандартів $Є С$ свою систему адміністративно-територіального устрою. По-четверте, нова мережа районів стане територіальною основою, необхідною для укріплення вертикалі виконавчої влади, побудови ефективної системи управління, створення належних умов для контролю держави над дотриманням законності. По-п'яте, запровадження нової мережі районів призведе 
до суттєвої економії коштів через скорочення кількості працівників у районних адміністраціях. По-шосте, реформа субрегіонального рівня дозволить уніфрікувати функції, кількісний склад працівників нових районних адміністрацій, унеможливить дублювання повноважень районних органів та органів місцевого самоврядування. Зрештою, по-сьоме, уже тепер в Україні де-сракто функціонує ціла низка міжрайонних структур у різних сорерах економічної діяльності та органах управління (статистиці, військових комісаріатах, медицині, податковій службі, прокуратурі тощо), що вказує на об'єктивну потребу укрупнення наявних адміністративних районів.

В Україні $є$ також противники укрупнення районів, до яких належать представники районної ланки управління, Українська асоціація районних та обласних рад, окремі науковці та експерти. Їхні аргументи, на жаль, не викладені в наукових публікаціях, а представлені чи то в соціальних мережах, чи в оглядових статтях засобів масової інфрормації [20]. Із урахуванням зауважень противників другого етапу адміністративно-територіальної реформи, а також власного бачення автором статті окремих його недоліків, можна навести такі аргументи "проти" укрупнення районів. По-перше, наявна мережа районів існує багато років, завдяки чому сформувалися відповідні системи розселення, транспортні комунікації, маршрути руху транспорту тощо. Новосформовані райони зумовлять порушення усталених зв'язків, що загалом негативно позначиться на якості надання послуг. По-друге, укрупнення районів погіршить транспорту доступність адміністративних, освітніх і медичних установ для населення. Традиційне твердження, що за "довідкою" доведеться добиратися 60-90 км, не позбавлене сенсу. Потретє, створення нових районів потребуватиме реформування транспортно-логістичної системи, зокрема маршрутів руху громадського транспорту, можливо прокладання нових транспортних комунікацій тощо, а це додаткові витрати 3 державного та місцевих бюджетів. Почетверте, новостворені райони, насамперед ті, що мають незначну кількість населення, потребуватимуть значних фрінансових витрат для "підтягування" їхньої інфрраструктури до субрегіонального рівня. По-п'яте, позбавлення колишніх районних центрів офріційного адміністративного статусу погіршить перебіг у них демографічних процесів і посилить деградацію закладів соціальної інфраструктури. Окремі експерти, зокрема О. Со- лонтай, $є$ противниками запровадження реформи субрегіонального рівня через те, що вона закріпить необґрунтовану трирівневу систему державного управління, а також через невирішеність питання бюджету й повноважень новостворених районів [20].

Зважаючи на наявність дискусійних моментів, а також з метою пришвидшення процесу формування нових районів, Міністерством регіонального розвитку, будівництва та житлово-комунального господарства України в січні 2019 р. було розроблено "Методичні рекомендації щодо критеріїв формування адміністративно-територіальних одиниць субрегіонального (районного) рівня" [14]. Відповідно до норм, які містяться в зазначеному документі, нові райони мають формуватися навколо міст із населенням не менше, ніж 50 тис. осіб, і налічувати не менше, ніж 150 тис. мешканців. Сфрера впливу нових центрів субрегіонального рівня має становитити орієнтовно 60 км. У методиці також зазначається, що нові райони можуть фрормуватися й навколо менших за людністю поселень, якщо в регіонах залишилися вільні території з населенням понад 150 тис. осіб. Кількісні параметри нових адміністративних одиниць указують на те, що в Україні планується створити райони, які відповідають рівню NUTS-3.

Перші проєктні ідеї поділу України на територіальні одиниці субрегіонального рівня з'явилися в Україні ще на початку 2000-х років. Так, О. Соскін пропонував виділити в Україні 42 паланки та 33 крайові міста з аналогічним статусом, П. Масляк - 96 паланок, центрами яких мали би стати переважно міста обласного підпорядкування [2, с. 131].

І. Коліушко в оприлюдненій 2015 р. моделі повітового устрою України пропонував сформувати в Україні 129 адміністративних одиниць субрегіонального рівня, у т. ч. 10 повітів у тимчасово окупованих районах Донбасу та вісім - в АР Крим [16]. Термін "повіт" для позначення адміністративних одиниць субрегіонального рівня в Україні не знайшов належної підтримки, але кількісний склад нових районів став предметом для активного обговорення.

У проєкті реформування адміністративного устрою країни, який було презентовано Міністерством регіонального розвитку, будівництва та житлово-комунального господарства влітку 2019 р., передбачалося створити в Україні 102 нові райони, у т. ч. 10 - на тимчасово окупованих територіях Донбасу та в Криму (табл. 1).

Таблиця 1. Кількість адміністративно-територіальних одиниць субрегіонального рівня в Україні за різними варіантами

\begin{tabular}{|c|c|c|c|c|c|c|c|}
\hline 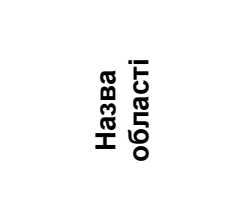 & 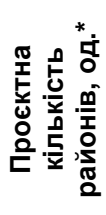 & 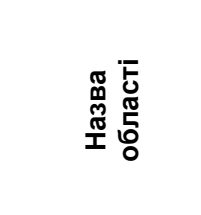 & 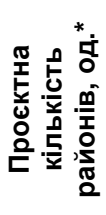 & 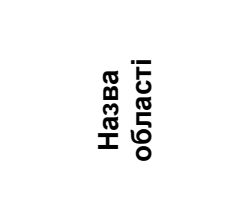 & 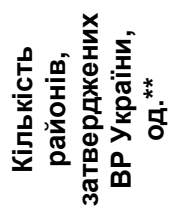 & 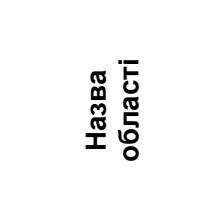 & 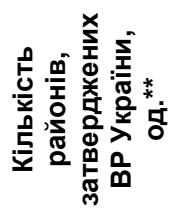 \\
\hline AР Крим & $0+4$ & Миколаївська & 4 & AР Крим & $0+10$ & Миколаївська & 4 \\
\hline Вінницька & 3 & Одеська & 4 & Вінницька & 6 & Одеська & 7 \\
\hline Волинська & 3 & Полтавська & 4 & Волинська & 4 & Полтавська & 4 \\
\hline Дніпропетровська & 5 & Рівненська & 3 & Дніпропетровська & 7 & Рівненська & 4 \\
\hline Донецька & $5+3$ & Сумська & 4 & Донецька & $5+3$ & Сумська & 5 \\
\hline Житомирська & 4 & Тернопільська & 3 & Житомирська & 4 & Тернопільська & 3 \\
\hline Закарпатська & 4 & Харківська & 4 & Закарпатська & 6 & Харківська & 7 \\
\hline Запорізька & 5 & Херсонська & 3 & Запорізька & 5 & Херсонська & 5 \\
\hline Ів.-Франківська & 5 & Хмельницька & 3 & Ів.-Франківська & 6 & Хмельницька & 3 \\
\hline Київська & 4 & Черкаська & 4 & Київська & 7 & Черкаська & 4 \\
\hline Кіровоградська & 3 & Чернівецька & 3 & Кіровоградська & 4 & Чернівецька & 3 \\
\hline Луганська & $3+3$ & Чернігівська & 4 & Луганська & $4+4$ & Чернігівська & 5 \\
\hline Львівська & 5 & Разом & $92+10$ & Львівська & 7 & Разом & $119 /+17$ \\
\hline
\end{tabular}

* - модель, розроблена Міністерством регіонального розвитку, будівництва і житлово-комунального господарства (2019 р.) [15]; ** - модель, затверджена Верховною Радою України Постановою № 807-ІХ від 17.07.2020 р. [19]. 
У 2020 р. після зміни влади, обговорення цього питання на рівні регіонів, експертів, представників Міністерства розвитку громад і територій кількість нових районів зросла до 129 одиниць [9]. Це сталося переважно завдяки збільшенню кількості районів на тимчасово окупованих територіях. Так, за першим варіантом пропонувалося створити в АР Крим чотири райони, тепер - 10. Збільшилася проти попереднього варіанта також кількість районів у Луганській області. Розробники проєкту пояснюють таку ситуацію необхідністю посилення присутності держави на територіях, де ведуться бойові дії.

Жваву дискусію викликали нові райони, які створені на територіях компактного проживання болгар (Болградський) та угорців (Берегівський). Думки учасників дискусії інколи $€$ полярними. Прикладом цього $€$ опитування трьох експертів-однодумців щодо реформи субрегіонального рівня, проведене компанією "Медіасапіенс". А. Ткачук та І. Лукерія не бачать нічого загрозливогоу формуванні таких районів, особливо зважаючи на те, що на сьогодні держава дещо ослаблена і ми не повинні створювати додаткові проблемні регіони. Натомість А. Ганущак уважає, що Берегівський та Болградський райони $є$ абсолютно штучними утвореннями, які $є$ наслідком міждержавних кулуарних домовленостей [21]. Частковим підтвердженням цього $є$ поява на карті України укрупненого Болградського району після ухвалення парламентом Болгарії Декларації "Про адміністративно-територіальну реформу в Республіці Україна та захисту прав і цілісності болгарської громади". Берегівського району в першому варіанті поділу Закарпатської області на нові адміністративні одиниці субрегіонального рівня також не було.

Після передачі офріційно затвердженого Кабінетом Міністрів складу адміністративних одиниць субрегіонального рівня на розгляд Верховної Ради України дискусії довкола питання реформування мережі районів продовжилися у цілому ряді регіонів. Під тиском протестувальників із регіонів країни, а також за наслідками додаткових консультацій Верховна Рада України Постановою № 807-ІХ від 17.07.2020 р. "Про утворення та ліквідацію районів" затвердила 136 районів (табл. 1).

Нові, порівняно з варіантом Кабінету Міністрів України, райони було створено у Вінницькій (Жмеринський), Дніпропетровській (Синельниківський), Закарпатській (Рахівський), Івано-Франківській (Верховинський), Київській (Броварський та Вишгородський), Одеській (Березнівський), Херсонській (Бериславський та Скадовський), Чернівецькій (Вижницький) та Чернігівській (Корюківський) областях. Водночас, у Київській області було ліквідовано Переяславський район, у Хмельницькій - Дунаївецький та Старокостянтинівський райони. У Харківській і Чернівецькій областях було змінено центри двох районів - Богодухів замість Люботина та Кельменці замість Хотина.

Почасти виокремлення нових адміністративно-територіальних одиниць субрегіонального рівня справді було складним завданням. Підтвердженням цього $є$ ситуація в Чернігівській області, де за право бути одним із центрів нового району боротьбу вели три практично рівноцінні міста. У кожному з них уже розміщуються міжрайонні осередки надання різних послуг: Мена є центром відділення податкової служби, Корюківка - госпітального округу, Новгород-Сіверський - центр нового району. За першим варіантом районування було виділено Північний район із центром у Корюківці, за другим - цей самий район із центром у Новгород-Сіверському, за третім - два райони - Корюківський та Новгород-Сіверський (рис. 1). "Боротьба" за право бути центром району супроводжувалася акціями протесту й пов'язана з лобіюванням "свого" районного центру представниками регіональних еліт.
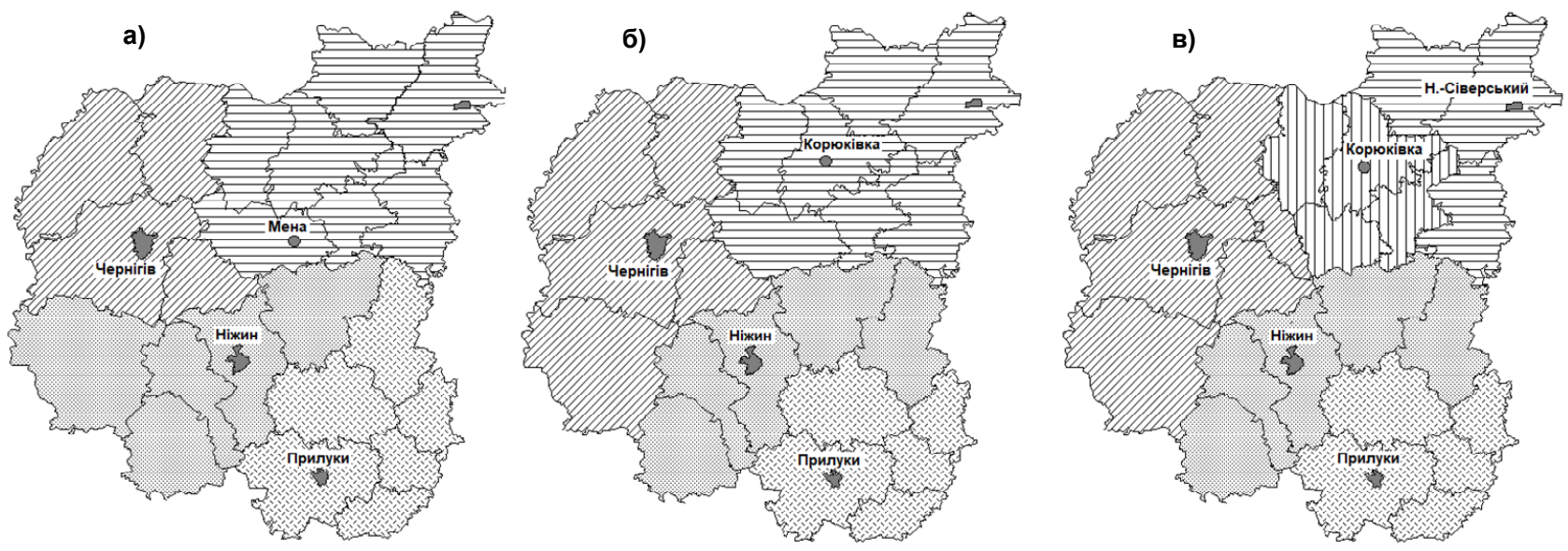

Рис. 1. Територіальні підрозділи державної податкової служби (а), госпітальні округи (б) та нові райони (в) Чернігівської області

Чи відповідає затверджений Верховною Радою України склад адміністративно-територіальних одиниць субрегіонального рівня положенням "Методики..." щодо їхнього створення? Обчислення показали, що пересічна кількість населення у нових районах становить наразі 303,2 тис. осіб, варіюючи від 1763 тис. осіб у Харківському до 30,5 тис. осіб у Верховинському (Ів.-Франківська область) районах. Добитися ситуації, коли всі райони мали б не менше, ніж 150 тис. осіб, не вдалося.
У 36 нових районах $(26,5$ \%) кількість населення є меншою за визначені "Методикою..." критеріїв, у т. ч. у 30 $(25,2 \%)$ районах без урахування тимчасово окупованих територій. Меншими за людністю виявилися практично всі райони, які були створені під час обговорення цього питання у Верховній Раді України. Так, у Чернігівській області розділення Північного району, який налічував понад 158,1 тис. осіб, на Корюківський та Н.-Сіверський призвело до утворення двох малолюдних районів із населенням 91,7 та 66,4 тис. осіб відповідно. 
Не вдалося також подолати проблему непропорційності районів, яка була одним із аргументів доцільності проведення адміністративної реформи субрегіонального рівня. Якщо до реформи максимальне значення людності району (Харківський район) перевищувало мінімальне (Поліський район) у 30 разів, то тепер ця різниця становить 58 разів (Харківський та Верховинський райони відповідно).

Поряд із питанням щодо кількості районів у кожному з регіонів, суперечливим у багатьох областях $€$ також перелік центрів нових районів. Відповідно до положень "Методики..." центрами районів мають бути міста з населенням не менш ніж 50 тис. осіб. Загалом пересічна людність центрів нових районів станом на кінець 2019 р. становить майже 130 тис. осіб. Диспропорції в людності центрів є дуже значними: від 1446 тис. осіб у м. Харкові до 4,0 тис. осіб - у м. Вижниця Чернівецької області. Половина поселень, які мають стати центрами районів, налічують менше, ніж 50 тис. осіб. Розміщуються вони переважно в регіонах із незначною кількістю населення та малою мережею міст. Майже 30 \% центрів нових районів не мають статусу міста обласного підпорядкування. Два міста - Вараш та Буча - взагалі не мали раніше статусу районного центру.

Аналіз динаміки людності центрів нових районів за 1989-2019 рр. свідчить про те, що левова частка із них характеризуються доволі стрімким скороченням населення. Лідерами таких негативних трендів $€$ міста Березівка (- 36,0 \%), Старобільськ $(-33,1 \%)$, Ромни $(-30,7 \%)$, Берислав (-29,1\%), Нікополь $(-29,8 \%)$ і Вижниця (29,8 \%). Лише близько 18 \% центрів перспективних районів мають позитивну динаміку кількості населення. Переважно, це міста Івано-Франківської, Тернопільської, Закарпатської та Київської областей.

Питання щодо кількості населення в центрі району також є дискусійним. 3 одного боку, в адміністративних центрах будуть зосереджені органи виконавчої влади i не важливо, скільки в них населення, головне, щоб ці органи працювали ефективно. При цьому критеріями "Методики..." можна знехтувати, оскільки вона офріційно не затверджена Кабінетом Міністрів України, має лише інформаційний характер, а в окремих регіонах дотриматися ії̈ норм неможливо через незначну мережу середніх міст. 3 іншого боку, як зазначає Ю. Ганущак, "...необхідність ефективності диктує особливі вимоги до адміністративних центрів, які мають стати привабливими для життя кваліфікованої адміністративної та секторальної еліти, яку можна виплекати в містах із населенням не менше, ніж 50 тис. осіб" [8]. Таке твердження $\epsilon$ абсолютно доречним, оскільки саме за такої людності місто має більш-менш належний рівень соціальної інфрраструктури, сектору розваг, достатню кількість якісного житла, офісних приміщень, необхідних для роботи префектури та територіальних представництв центральних органів виконавчої влади.

Попри те, що перелік адміністративно-територіальних одиниць субрегіонального рівня офріційно затверджений Верховною Радою України, досі нерозв'язаною $є$ низка питань їхнього подальшого функціонуванням. Як зазначають автори ідеї адміністративно-територіальної реформи, нові райони створюються винятково для організації виконавчої влади. Їхня головна функція - нагляд за дотриманням Конституції та законів. Стосовно інших повноважень, то вони наразі остаточно не визначені. Во- чевидь нові райони мають відповідати за вторинний рівень медицини, фахову передвищу освіту, соціальний захист населення, логістику, місцеву екологічну політику. У центрах нових районів мають бути зосереджені всі територіальні підрозділи центральних органів влади: суди, прокуратура, податкова служба, управління госпітальних округів тощо. Це дозволить впорядкувати територіальну організацію влади, оскільки на даний момент зазначені підрозділи розміщуються в різних поселеннях, що ускладнює їхню доступність для населення.

Не менш актуальними для функціонування нових районів $є$ фінансові й майнові питання. Вони мали би бути розв'язані ще до затвердження мережі адміністративно-територіальних одиниць субрегіонального рівня. Наразі у Верховній Раді України проходять обговорення два законопроєкти - № 3614 "Про внесення змін до Бюджетного кодексу України щодо приведення у відповідність положень бюджетного законодавства у зв'язку із завершенням адміністративно-територіальної реформи" та № 3651 "Про внесення змін до деяких законодавчих актів України щодо впорядкування окремих питань діяльності та організації органів державної влади, органів місцевого самоврядування у зв'язку 3 утворенням (ліквідацією) районів", які мають прямий стосунок до розв'язання фінансових і майнових питань. Попереднє обговорення цих законопроєктів у комітетах Верховної Ради України показало, що вони мають ряд недоліків, починаючи з визначення джерел фінансування і завершуючи переліком майна, яке буде перебувати у власності нових районів.

Затвердження мережі нових районів $є$ лише першим кроком на шляху до запровадження повноцінної адміністративної реформи субрегіонального рівня. Вона має стати важливим підґрунтям для ефективної територіальної організації влади в Україні.

Висновки. Другий етап реформування адміністративного-територіального устрою України розпочався дуже швидко, чим зумовив цілу низку дискусійних питань. У процесі його реалізації в середовищі експертів були як прихильники, так і противники цієї реформи. Однак зрозуміло, що завершення процесу формування територіальних громад, наявність де-факто цілої низки міжрайонних систем управління в різних сфрерах економічної діяльності, ставлять під сумнів доцільність збереження адміністративних районів у їхньому попередньому складі. Після обговорення й узгодження Верховна Рада України в липні 2020 р. затвердила перелік адміністративно-територіальних одиниць субрегіонального рівня. Формування нових районів є ще одним кроком до імплементації європейської практики територіального управління, оскільки за кількістю населення адміністративно-територіальні одиниці субрегіонального рівня відповідатимуть рівню NUTS-3 територіальних статистичних одиниць ЄC.

Проведене дослідження показало, що офріційно затверджений перелік нових районів не $є$ досконалим щодо його відповідності критеріям чинної нормативної бази. У 26,5 \% нових районів кількість населення є меншою, ніж 150 тис. осіб, у т. ч. практично в усіх районах, які були створені під тиском представників регіонів. Диспропорції у кількості населення в районах, порівняно зі старою схемою адміністративного устрою, зросли із 30 до 58 разів. У половині центрів нових районів кількість населення $€$ меншою, ніж 50 тис. осіб, що може стати додатковою перешкодою для формування 
якісного кадрового потенціалу органів виконавчої влади. Формування меж нових районів відбувалося без урахування наявних тепер міжрайонних систем управління в освіті, медицині, податковій службі. Усталені стереотипи, а також прагнення місцевих еліт зберегти за собою контроль над певними територіями, були головними стимулами боротьби окремих міст за статус центра нового району. У середовищі експертів немає одностайної думки стосовно доцільності створення адміністративних одиниць субрегіонального рівня за етнічною ознакою (Берегівський та Болградський райони), особливо зважаючи на обставини, під впливом яких приймалося це рішення.

Формування адміністративно-територіальних одиниць субрегіонального рівня $є$ лише першим кроком на шляху побудови в Україні ефективної моделі територіальної організації влади. Попри те, що мережа нових районів затверджена, дослідження в царині реформи адміністративного устрою мають продовжуватися. Перспективними в цьому контексті $€$ питання оцінки матеріального та кадрового потенціалу центрів нових районів для виконання покладених на них функцій, розроблення пропозицій із оптимізації розміщення територіальних підрозділів центральних органів виконавчої влади.

\section{Список використаних джерел}

1. Адміністративно-територіальна реформа: бачення місцевих громад Луганщини / упорядники: Ю. Ращупкіна, В. Щербаченко. Луганськ, 2007

2. Адміністративно-територіальна реформа в Україні: оптимальна модель / за заг. ред. О. І. Соскіна. - Київ, 2007.

3. Адміністративно-територіальний устрій України. Історія Сучасність. Перспективи: монографія / В. С. Куйбіда, В.П.Павленко, В. А. Яцюк та ін. - Київ, 2009.

4. Адміністративно-територіальний устрій України: методологічні основи та практика реформування: монографрія / наук. ред. В.С. Кравців. - Львів, 2016.

5. Барановський М. О. Фінансова децентралізація в Україні: особливості становлення [Електронний ресурс] / М. О. Барановський // Укр. геогр. журн. - 2017. - № 4. - Режим доступу: https://doi.org/ 10.15407/ugz2017.04.030

6. Беновська Л.Я. Посилення диференціації розвитку територіальних громад як ризик реформи децентралізації [Електронний ресурс] // Регіональна економіка. - 2019. - № 1 (91). Режим доступу: https://doi.org/10.36818/1562-0905-2019-1-3

7. Ганущак Ю. Реформа територіальної організації влади: монографія / Ю. Ганущак. - Київ, 2013.

8. Ганущак Ю. Як правильно "нарізати" райони? / Ю. Ганущак [Електронний ресурс]. - Режим доступу: https://zn.ua/ukr/economics_of_ regions/yak-pravilno-narizati-rayoni-346351 .html

9. Децентралізація. Нові райони [Електронний ресурс]. - Режим доступу: https://decentralization.gov.ua/new-rayons/ar-krym

10. Для кого нові райони: міфи ра реалії нового адмінтерустрою в Україні [Електронний ресурс]. - Режим доступу: https://uacrisis.org/uk/ dlya-kogo-novi-rajony-mify-ta-realiyi-novogo-adminterustroyu-v-ukrayini

11. Дністрянський М. С. Кордони України. Територіальноадміністративний устрій / М. С. Дністрянський. - Львів, 1992.

12. Дністрянський М. С. Адміністративно-територіальний устрій України крізь призму геополітики / М. С. Дністрянський // Дзвін. - 1996. - Вип. 8.

13. Мельничук А Остапенко П. Децентралізація влади: реформа № 1: аналітичні записки / А. Мельничук, П. Остапенко. - Київ, 2016.

14. Методичні рекомендації щодо критеріїв формування адміністративно-територіальних одиниць субрегіонального (районного) рівня. Київ, 2019. URL: https://www.minregion.gov.ua/wp-content/uploads/ 2019/08/Metod.recom_.rayon_.pdf

15. Національний проект "Децентралізація" [Електронний ресурс]. - Режим доступу: www.facebook.com/zubko.gennadiy/posts/2391177131164453/

16. Новий адміністративний устрій: в Україні з'являться громади, повіти й регіони [Електронний ресурс]. - Режим доступу: https://texty.org.ua/fragments/60093/Novyj_administratyvnyj_ustrij_v_Ukrajini_ zjavlatsa gromady-60093

17. Олійник Я. Б. Формування спроможних територіальних громад в Україні: переваги, ризики, загрози / Я. Б. Олійник, П. О. Остапенко // Укр. геогр. журн. №4. 2016. https://doi.org/10.15407/ugz2016.04.037

18. Піх О. М. Впровадження адміністративно-територіальної реформи в Україні через призму польського досвіду/ О. М. Піх
// Соціально-економічні проблеми сучасного періоду України. - 2014. Вип. 2 (106).

19. Про утворення та ліквідацію районів: Постанова Верховної Ради України № 807-ІХ від 17.07.2020 р. [Електронний ресурс]. - Режим доступу: https://zakon.rada.gov.ua/laws/show/807-IX\#Text

20. Сардалова А. Нова діжка, старе вино: за що критикують новий поділ на райони і що кажуть його прихильники [Електронний ресурс]. Режим доступу: https://www.radiosvoboda.org/a/krytyka-novoho-podilu-narayony/30701785.htm

21. Скляревська Г. Самогубство чи нормальний процес? Експерти роз'яснюють утворення нових районів [Електронний ресурс]. - Режим доступу: https://ms.detector.media/trendi/post/24866/2020-06-13-samogubstvo-chinormalnii-protses-eksperti-rozyasnyuyut-utvorennya-novikh-raioniv-v-ukraini/

22. Територіальні громади в умовах децентралізації: ризики та механізми розвитку: монографія / за ред. В. С. Кравціва, І. З. Сторонянської. - Львів, 2020.

23. Територіальний розвиток в Україні: розвиток агломерацій та субрегіонів. Київ, 2012. URL: http://2.auc.org.ua/sites/all/sites/default/files/ files/Subregional_Structures_Development_2012.pdf

24. Тітенко 3. В. Проблеми та перспективи адміністративнотериторіальної реформи в Україні // Ученые записки Таврич. нац. ун-та им. В. И. Вернадского / З. Тітенко // Науч. журн. Серия "География". Сімферополь, 2011.

25. Ткачук А. 3 історії рефрорм адміністративно-територіального устрою України, 1907-2009 роки / Ткачук А., Ткачук Р., Ганущак Ю.. Київ, 2009.

26. Decentralization reform in Ukraine: assessment of the chosen transformation model / V. Udovychenko, A. Melnychuk, O. Gnatiuk, P. Ostapenko // European Spatial Research and Policy. - 2017. - User. 24. - № 1.

\section{References}

1. Administratyvno-terytorial'na reforma: bachennya mistsevykh hromad Luhanshchyny / uporyadnyky: YU. Rashchupkina, V. Shcherbachenko. Luhans'k, 2007

2. Administratyvno-terytorial'na reforma $v$ Ukrayini: optymal'na model' I Za zah. redak. O. I. Soskina. Kyyiv, 2007.

3. Administratyvno-terytorial'nyy ustriy Ukrayiny. Istoriya. Suchasnist'. Perspektyvy: monohrafiya / V. S. Kuybida, V. P. Pavlenko, V. A. Yatsyuk ta in. Kyyiv, 2009

4. Administratyvno-terytorial'nyy ustriy Ukrayiny: metodolohichni osnovy ta praktyka reformuvannya: monohrafiya / nauk. red. V. S. Kravtsiv. L'viv, 2016.

5. Baranovs'kyy M. O. Finansova detsentralizatsiya v Ukrayini: osoblyvosti stanovlennya // Ukrayins'kyy heohrafichnyy zhurnal. № 4. 2017. https://doi.org/10.15407/ugz2017.04.030

6. Benovs'ka L. YA. Posylennya dyferentsiatsiyi rozvytku terytorial'nykh hromad yak ryzyk reformy detsentralizatsiyi / Rehional'na ekonomika. 2019. № 1 (91). DOI: https://doi.org/10.36818/1562-0905-2019-1-3.

7. Hanushchak YU. Reforma terytorial'noyi orhanizatsiyi vlady: monohrafiya. Kyyiv, 2013.

8. Hanushchak YU. Yak pravyl'no "narizaty" rayony? URL: https://zn.ua/ ukr/economics of regions/yak-pravilno-narizati-rayoni-346351 .html

9. Detsentralizatsiya. Novi rayony. URL: https://decentralization.gov.ua/ new-rayons/ar-krym

10. Dlya koho novi rayony: mify ra realiyi novoho adminterustroyu $v$ Ukrayini. URL: https://uacrisis.org/uk/dlya-kogo-novi-rajony-mify-ta-realiyinovogo-adminterustroyu-v-ukrayin

11. Dnistryans'kyy M.S. Kordony Ukrayiny. Terytorial'noadministratyvnyy ustriy. L'viv, 1992.

12. Dnistryans'kyy M. S. Administratyvno-terytorial'nyy ustriy Ukrayiny kriz' pryzmu heopolityky // Dzvin. Vyp. 8, 1996.

13. Mel'nychuk A., Ostapenko P. Detsentralizatsiya vlady: reforma №1: analitychni zapysky. Kyyiv, 2016.

14. Metodychni rekomendatsiyi shchodo kryteriyiv formuvannya administratyvno-terytorial'nykh odynyts' subrehional'noho (rayonnoho) rivnya. Kyyiv, 2019. URL: https://www.minregion.gov.ua/wp-content/uploads/ 2019/08/Metod.recom .rayon .pdf

15. Natsional'nyy proekt "Detsentralizatsiya". URL: www.facebook.com/zubko.gennadiy/posts/2391177131164453/

16. Novyy administratyvnyy ustriy: v Ukrayini z"yavlyat'sya hromady, povity y rehiony. URL: https://texty.org.ua/fragments/60093/Novyj administratyvnyj_ustrij_v_Ukrajini_zjavlatsa_gromady-60093/

17. Oliynyk YA. B., Ostapenko P. O. Formuvannya spromozhnykh terytorial'nykh hromad v Ukrayini: perevahy, ryzyky, zahrozy // Ukrayins'kyy heohrafichnyy zhurnal. № 4. 2016. https://doi.org/10.15407/ugz2016.04.037

18. Pikh O. M. Vprovadzhennya administratyvno-terytorial'noyi reformy v Ukrayini cherez pryzmu pol's'koho dosvidu / Sotsial'no-ekonomichni problemy suchasnoho periodu Ukrayiny. Vyp. 2 (106), 2014

19. Pro utvorennya ta likvidatsiyu rayoniv. Postanova Verkhovnoyi Rady Ukrayiny №807-IKH vid 17.07.2020 r. URL: https://zakon.rada.gov.ua/ laws/show/807-IX\#Text

20. Sardalova $A$. Nova dizhka, stare vyno: za shcho krytykuyut' novyy podil na rayony i shcho kazhut' yoho prykhyl'nyky. URL: https://www.radiosvoboda.org/a/krytyka-novoho-podilu-na-rayony/30701785.html 
21. Sklyarevs'ka H. Samohubstvo chy normal'nyy protses? Eksperty roz"yasnyuyut' utvorennya novykh rayoniv. URL: https://ms.detector.media/ trendi/post/24866/2020-06-13-samogubstvo-chi-normalnii-protses-ekspertirozyasnyuyut-utvorennya-novikh-raioniv-v-ukraini/

22. Terytorial'ni hromady $v$ umovakh detsentralizatsiyi: ryzyky ta mekhanizmy rozvytku: monohrafiya / za red. Kravtsiva V. S., Storonyans'koyi I. Z. L'viv, 2020.

23. Terytorial'nyy rozvytok $v$ Ukrayini: rozvytok ahlomeratsiy ta subrehioniv. Kyyiv, 2012. URL: http://2.auc.org.ua/sites/all/sites/default/files/ files/Subregional_Structures_Development_2012.pdf
24. Titenko Z. V. Problemy ta perspektyvy administratyvnoterytorial'noyi reformy $\mathrm{v}$ Ukrayini / Uchenye zapysky Tavrycheskoho natsyonal'noho unyversytet ym. V. Y. Vernadskoho. Nauchnyy zhurnal. Seryya "Heohrafyya". Simferopol', 2011.

25. Tkachuk A. Tkachuk $R$, Hanushchak YU $Z$ istoriyi reform administratyvno-terytorial'noho ustroyu Ukrayiny, 1907-2009 roky. Kyyiv, 2009.

26. Udovychenko V., Melnychuk A., O Gnatiuk O., Ostapenko P. Decentralization reform in Ukraine: assessment of the chosen transformation model // European Spatial Research and Policy, 2017. User. 24. № 1.

Надійшла до редколегії 30.06.20

Н. Барановский, д-р геогр. наук, проф.

Нежинский государственный университет имени Николая Гоголя, Нежин, Украина

\section{СУБРЕГИОНАЛЬНЫЙ УРОВЕНЬ \\ АДМИНИСТРАТИВНО-ТЕРРИТОРИАЛЬНОЙ РЕФОРМЫ В УКРАИНЕ: ДИСКУССИОННЫЕ АСПЕКТЫ}

В Украине начался второй этап децентрализации, связанный с формированием административно-территориальных единиц субрегионального уровня. Утвержденный Верховным Советом Украины перечень новых районов содержит ряд дискуссионных моментов, которые требуют научного анализа. В исследовании проанализированы подходы ученых к выделению в Украине административнотерриториальных единиц субрегионального уровня, раскрыты аргументы сторонников и противников их создания в современных условиях. На основе анализа количественных критериев установлено, что новые проектные районы соответствуют уровню NUTS-3 стандарта территориального деления стран ЕС. Осуществлен сравнительный анализ схем деления страны на районы, которые были разработаны разными правительствами Украины, с сетью районов, утвержденных Верховным Советом в 2020 г. Установлено, что увеличение количества новых районов со 102 до 128, а далее до 136 единиц, произошло вследствие расширения их сети на временно оккупированных территориях и в Крыму, а также под давлением представителей регионов. На примере Черниговской области раскрыто сложность вопроса формирования сети новых районов и их центров. Определено, что среднее количество населения нового района составляет в Украине 303 тыс. человек, людность центра административных единиц субрегионального уровня - 130 тыс. человек. Установлено наличие очень значительных диспропорций (от 58 до 362 раз) в количестве населения в новых районах и в их центрах. На основе проведенных расчетов определено, что $26,5 \%$ новых районов и 50 \% их иентров имеют количество населения меньшее, нежели это предусмотрено нормативными документами, что может стать дополнительной преградой для формирования качественного кадрового потенциала органов исполнительной власти. Установлено, что конкурентная борьба между городами за статус центра нового района обусловлена желанием местных элит сохранить за собой контроль над определенными территориями. Указано на неоднозначное восприятие экспертами и региональными элитами вопроса создания новых районов по этническому признаку (Болградский и Береговский районы). Определен перечень кадровых, финансовых, имущественных вопросов, которые необходимо будет решить для построения в Украине эффективной исполнительной власти на субрегиональном уровне.

Ключевые слова: административно-территориальная реформа, субрегиональный уровень управления, проектные районы, административно-территориальное устройство, децентрализация.

M. Baranovskyi, Dr.Sc.,Geography, Professor

Nyzhin Mykola Gogol State University, Nyzhin, Ukraine

\section{SUBREGIONAL LEVEL \\ OF ADMINISTRATIVE AND TERRITORIAL REFORM IN UKRAINE: DEBATABLE ASPECTS}

Reforming the administrative and territorial structure of Ukraine within the process of decentralization has a number of unresolved issues. The second stage of the reform related to the formation of administrative and territorial units of the subregional level has now begun. The plan of 136 new districts approved by the Verkhovna Rada of Ukraine provoked a lively discussion both in the regions and in the expert community. The study analyses the approaches of scholars to the creation of administrative units of the subregional level in Ukraine in order to switch to a three-level model of territorial division. The article provides the arguments for and against the creation of new administrative and territorial units of the subregional level in Ukraine. The existence de facto in Ukraine of a number of inter-district territorial systems in various spheres - education, medicine, tax service - has been proved. Based on the analysis of quantitative criteria, written in the methodology for creation of new districts, it was defined that they met the NUTS-3 level of the territorial division standard of the European Union countries. A comparative analysis of schemes for dividing the country into districts, which were developed by different Governments of Ukraine, and the network of districts approved by the Verkhovna Rada in 2020 was carried out. The article presents reasons for the increase in the number of new districts from 102 to 129 and then to 136 units, primarily due to the extension of their network in the temporarily occupied territories of Donbas and Crimea, as well as under pressure from regional representatives. The complexity of the issue of forming a network of new districts and their centres are described on the example of Chernihiv region. It is determined that the average population of the project district in Ukraine is 303 thousand people, the population of the centre of administrative units of the subregional level, 130 thousand people. The significant disparities (from 58 to 362 times) in the population of new districts and their centres were defined. Based on the calculations, it was found that $26,5 \%$ of new districts have less population than that determined by the methodology of forming administrative units of the subregional level (150 thousand people). The situation with the population of district centres is similar. Almost $50 \%$ of subregional centres approved by the Verkhovna Rada of Ukraine account for less than 50 thousand people, which may be an obstacle to form high-quality human resources of the executive bodies. It is defined that the competition between cities for the status of the new district centre is due to the desire of local elites to retain control over certain areas. The ambiguous attitude to the issue of creating administrative units of the subregional level on ethnic grounds (Bolhrad and Berehovo districts) among experts and regional elites is pointed out. The list of personnel, financial, property issues that need to be resolved in order to build an effective executive branch in Ukraine at the subregional level has been determined.

Keywords: administrative and territorial reform, subregional level of management, project districts, administrative and territorial structure, decentralization. 